\title{
$p$-n Interface stabilization of planar heterojunction organic photovoltaics by an ethyleneoxy side chain of methanofullerenes
}

\author{
Akuto Takagi ${ }^{\mathrm{a}}$, Tadashi Mizutani*a ${ }^{*}$, Kazuyuki Moriwaki ${ }^{\mathrm{b}}$, Yuko Takao ${ }^{\mathrm{b}}$, Fukashi Matsumoto ${ }^{\mathrm{b}}$, Koichi \\ Hida $^{\mathrm{b}}$, Toshiyuki Iwai ${ }^{\mathrm{b}}$, Takatoshi Ito ${ }^{\mathrm{b}}$, Takumi Mizuno ${ }^{\mathrm{b}}$, and Toshinobu Ohno*a,b \\ ${ }^{a}$ Department of Molecular Chemistry and Biochemistry, Faculty of Science and Engineering, \\ Doshisha University, Kyotanabe, Kyoto 610-0321, Japan
}

${ }^{b}$ Osaka Municipal Technical Research Institute, 1-6-50, Morinomiya, Joto-ku, Osaka 536-8553, Japan

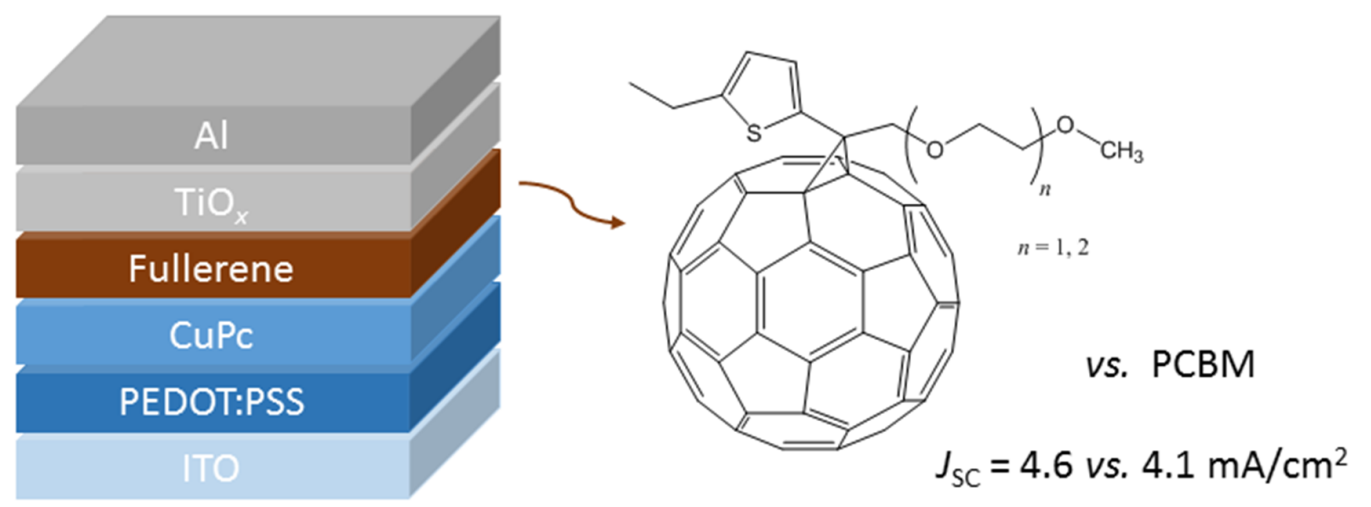

\begin{abstract}
Methanofullerenes bearing both an ethyleneoxy side chain, $-\left(\mathrm{CH}_{2} \mathrm{CH}_{2} \mathrm{O}\right)_{n^{-}}, n=1$ or 2, and a 5-ethyl2-thienyl group were prepared. These methanofullerenes were much more polar than PCBM and $\mathrm{C}_{60}$, and solubility in chlorobenzene (23-24 g/L) was comparable to that of PCBM. Planar heterojunction photovoltaic cells employing the methanofullerenes as an electron acceptor and copper phthalocyanine $(\mathrm{CuPc})$ as an electron donor were fabricated. The short-circuit current density of the photovoltaic cell (4.61-4.66 $\mathrm{mA} / \mathrm{cm}^{2}$ ) was larger than that of the photovoltaic cell prepared from the standard fullerene acceptor, PCBM, (4.08 $\left.\mathrm{mA} / \mathrm{cm}^{2}\right)$, and consequently the power conversion efficiency was improved. Comparisons of contact angles of water and hexadecane on fullerene films indicated that the fullerenes with an ethyleneoxy side chain formed more stable interface with CuPc than PCBM. These results suggest that side chain engineering aiming at stable $p$ - $n$ interface is an attractive strategy for designing efficient organic photovoltaic cells.
\end{abstract}

Keywords: fullerene, organic photovoltaic cell, interface 
Corresponding author's e-mail: tmizutan@mail.doshisha.ac.jp

\section{Introduction}

Organic photovoltaics (OPVs) $[1,2,3,4,5,6,7,8]$ attract interest owing to several advantages over silicon based ones, such as light weight, mechanical flexibility, and low cost for fabrication. The solution-based processes for device fabrication at low temperatures are compatible with usage of plastics or thermally unstable organic materials as a component of the cell. Design of the molecular structures of organic active layers through organic synthesis to optimize molecular orbitals and interface structures is also attractive features of OPVs. A planar heterojunction photovoltaic cell, in which copper phthalocyanine $(\mathrm{CuPc})$ and a perylenetetracarboxylic acid derivative were used as an electron donor and an electron acceptor layers, respectively, was first reported by Tang in 1979 [9,10], and its simple structure attracted much interest of researchers with continuing efforts to improve the energy conversion efficiency. Conjugated polymers [11] and other cyclic tetrapyrroles $[12,13]$ have been used as donor materials, and fullerenes [14,15,16,17] nano carbon, and electron deficient aromatic compounds have been used as acceptor materials [18]. One of the successful examples is a combination of $\mathrm{CuPc}$ and methanofullerenes with phenylbutyric acid ester moiety, i.e., [6,6]-phenyl$\mathrm{C}_{61}$-butyric acid methyl ester, PCBM [19], in place of $\mathrm{C}_{60}$; the lower LUMO energy level of PCBM reduced the energy loss during the electron transfer and resulted in improvement of the open-circuit voltage, $V_{\mathrm{OC}}$, as reported by Yang et al. [20] Because the energy conversion efficiency, $\eta$, is given by $\eta=\left(V_{\mathrm{OC}} J_{\mathrm{SC}} \mathrm{FF}\right) / P_{0}$, where $J_{\mathrm{SC}}$ is the short-circuit current density, $\mathrm{FF}$ is the fill factor, and $P_{0}$ is the incident light power density, a larger value of $V_{\mathrm{OC}}$ lead to higher energy conversion efficiency. The voltage generated by the organic photovoltaic cell, $V_{\mathrm{OC}}$, is related to the energy gap between the HOMO energy level of the donor and the LUMO energy level of the acceptor materials [21,22], so that control of the HOMO/LUMO energy levels of the electron donors and acceptors is important to optimize the performance of OPVs. We also reported that the HOMO/LUMO energy levels of organic active layers can be controlled by introducing appropriate polar substituents to fullerenes [23] and subphthalocyanines [24].

The current generated by the photovoltaic cell, $J_{\mathrm{SC}}$, depends on a variety of factors, such as efficiency of photon absorption, efficiency of charge separation, the surface area of the $p$ - $n$ junction, the mobility of the charge carriers, and so on. For OPVs employing a semiconductive polymer as a donor material, side chain engineering or addition of a small molecule to improve the morphology of bulk $p$ - $n$ heterojunction were successful to improve the energy conversion efficiency of OPVs $[25,26,27]$. Therefore, control of the interface structures, particularly, at the $p$ - $n$ junction, should be important to design the efficient OPVs [28,29]. It is not well understood how the molecular structures

of donor and acceptor molecules affect stability of the interface and the efficiency of the resulting OPVs. 
We prepared methanofullerene derivatives with an ethyleneoxy side chain and compared their physicochemical properties and OPV performance with PCBM, a methanofullerene derivative used as a standard electron acceptor, to examine whether the polar side chain could affect stability of $p-n$ heterojunction and the performance of the OPVs. Although polyethylene glycol appended fullerenes have been used for conjugated polymer-based OPVs [30,31], they have not been combined with small molecule donors. We found that introduction of an ethyleneoxy side chain resulted in a larger current density, and improved the energy conversion efficiency of the OPVs.

\section{Experimental}

\subsection{Synthesis of fullerenes}

NMR experiments were performed with a JEOL JNM-ECA500 spectrometer. Tetramethylsilane was used as an internal standard of ${ }^{1} \mathrm{H}$ and ${ }^{13} \mathrm{C}$ NMR spectra. Matrix-assisted laser desorption-ionization time-of-flight mass (MALDI-TOF MS) spectra were recorded on a Bruker Daltonics Autoflex Speed spectrometer. The contact angles of water and hexadecane on the film of methanofullerenes were determined by use of CA-X150, Kyowa Interface Science Co., Ltd. Cyclic voltammetry was performed for the solutions of the methanofullerenes in $o$-dichlorobenzene (ODCB) in the presence of $0.1 \mathrm{M}$ tetrabutylammonium perchlorate used as a supporting electrolyte.

\subsubsection{Synthesis of 1-(5-ethyl-2-thienyl)-1-(2-methoxyethoxy)methyl-[6,6]-methanofullerene[60]} (1)

\subsubsection{5-Ethyl-2-thienyl (2-methoxyethoxy)methyl ketone (6)}

2-(2-Methoxyethoxy)acetic acid $4(3.89 \mathrm{~g}, 29.0 \mathrm{mmol})$ was dissolved in $20 \mathrm{~mL}$ of anhydrous dichloromethane, and then $4.06 \mathrm{~g}$ (32.0 mmol) of oxalyl chloride was added dropwise under Ar over $5 \mathrm{~h}$ with stirring. Then 2-ethylthiophene $(3.17 \mathrm{~g}, 28.2 \mathrm{mmol})$ was added at $0{ }^{\circ} \mathrm{C}$ into the mixture, followed by the dropwise addition of $1 \mathrm{M}$ tin(IV) chloride in dichloromethane $(32 \mathrm{~mL})$. The reaction mixture was stirred at room temperature for another $16 \mathrm{~h}$. Then $c a .70 \mathrm{~mL}$ of $1.0 \mathrm{M}$ hydrochloric acid was added to quench the reaction, and the mixture was washed with distilled water until the washing was neutral, and with brine. The organic layer was dried over anhydrous sodium sulfate, and evaporated. Ketone 6 was isolated with silica gel chromatography (ethyl acetate: $n$-hexane $=1: 1$ ) and the yield was $1.22 \mathrm{~g}(19 \%)$.

6: ${ }^{1} \mathrm{H}$ NMR (500 MHz, $\left.\mathrm{CDCl}_{3}\right): \delta(\mathrm{ppm}) 7.71$ (d, $\left.1 \mathrm{H}, 4.0 \mathrm{~Hz}\right), 6.84$ (d, 1H, $\left.3.5 \mathrm{~Hz}\right), 4.63(\mathrm{~s}, 2 \mathrm{H}), 3.78$

(t, 2H), $3.62(\mathrm{t}, 2 \mathrm{H}), 3.39$ (s, 3H), 2.89 (q, 2H), 1.33 (t, 3H); ${ }^{13} \mathrm{C} \mathrm{NMR}\left(125 \mathrm{MHz}, \mathrm{CDCl}_{3}\right): \delta(\mathrm{ppm})$ $189.56,157.69,138.46,133.08,125.05,74.42,71.93,70.88,59.00,23.97,15.56$.

\subsubsection{N'-[1-(5-Ethyl-2-thienyl)-2-(2-methoxyethoxy)ethylidene]-4- methylbenzenesulfonohydrazide (7)}


Ketone 6 (1.14 g, $5.0 \mathrm{mmol})$ and $p$-toluenesulfonyl hydrazide $(1.12 \mathrm{~g}, 6.0 \mathrm{mmol})$ were dissolved in $10 \mathrm{~mL}$ of ethanol, and the solution was stirred for $24 \mathrm{~h}$ at room temperature. Confirming the completion of the reaction by reverse phase HPLC, the solvent was removed by a rotary evaporator. The product was dissolved in a minimum amount of ethyl acetate, and then recrystallized by adding $n$-hexane, yielding $1.54 \mathrm{~g}(78 \%)$ of 7 .

7: ${ }^{1} \mathrm{H}$ NMR (500 MHz, $\mathrm{CDCl}_{3}$ ): $\delta(\mathrm{ppm}) 9.70(\mathrm{~s}, 1 \mathrm{H}), 7.87$ (d, 2H, $\left.8.5 \mathrm{~Hz}\right), 7.28$ (d, 2H, $\left.8.0 \mathrm{~Hz}\right), 6.97$ (d, 1H, $4.0 \mathrm{~Hz}), 6.61(\mathrm{~d}, 1 \mathrm{H}, 3.5 \mathrm{~Hz}), 4.57(\mathrm{~s}, 2 \mathrm{H}), 3.52(\mathrm{t}, 2 \mathrm{H}), 3.49$ (t, 2H), $3.41(\mathrm{~s}, 3 \mathrm{H}), 2.77(\mathrm{q}, 2 \mathrm{H})$, $2.38(\mathrm{~s}, 3 \mathrm{H}), 1.27(\mathrm{t}, 3 \mathrm{H}) ;{ }^{13} \mathrm{C}$ NMR (125 MHz, $\left.\mathrm{CDCl}_{3}\right): \delta(\mathrm{ppm}) 151.37,145.41,143.54,138.19$, 135.95, 129.30, 127.98, 126.43, 123.59, 71.14, 69.67, 66.73, 59.05, 23.63, 21.49, 15.56; MALDI TOFMS: $397(\mathrm{M}+\mathrm{H})^{+}$; Anal. Calcd for $\mathrm{C}_{18} \mathrm{H}_{24} \mathrm{~N}_{2} \mathrm{O}_{4} \mathrm{~S}_{2}$ : C, 54.52; H, 6.10; N, 7.06; S, 16.17. Found: $\mathrm{C}$, $54.45 ; \mathrm{H}, 6.34 ; \mathrm{N}, 6.84 ; \mathrm{S}, 16.41$.

\subsubsection{1-(5-Ethyl-2-thienyl)-1-(2-methoxyethoxy)methyl-[6,6]-methanofullerene[60] (1)}

Under Ar atmosphere, hydrazide $7(154 \mathrm{mg}, 0.39 \mathrm{mmol})$ and $1 \mathrm{M}$ potassium tert-butoxide in THF $(0.42 \mathrm{~mL})$ were dissolved in $2 \mathrm{~mL}$ of anhydrous $o$-dichlorobenzene (ODCB) and the solution was stirred for $15 \mathrm{~min}$. Then a solution of $\mathrm{C}_{60}(200 \mathrm{mg}, 0.28 \mathrm{mmol})$ in ODCB $(8 \mathrm{~mL})$ was added to it, and the solution was stirred for $4 \mathrm{~h}$ at $130{ }^{\circ} \mathrm{C}$ under Ar while irradiating with light. The reaction mixture was subjected to silica gel chromatography (toluene, $50 \mathrm{~mm} \phi$ ), and then preparative gelpermeation HPLC (20 $\mathrm{mm} \phi)$, to yield $122 \mathrm{mg}(43 \%)$ of $\mathbf{1}$.

1: ${ }^{1} \mathrm{H}$ NMR (500 MHz, $\left.\mathrm{CDCl}_{3}\right): \delta(\mathrm{ppm}) 7.35(\mathrm{~d}, 1 \mathrm{H}, 3.5 \mathrm{~Hz}), 6.80(\mathrm{~d}, 1 \mathrm{H}, 3.5 \mathrm{~Hz}), 4.85(\mathrm{~s}, 2 \mathrm{H}), 3.89$ (t, 2H), $3.65(\mathrm{t}, 2 \mathrm{H}), 3.41(\mathrm{~s}, 3 \mathrm{H}), 2.95(\mathrm{q}, 2 \mathrm{H}), 1.41(\mathrm{t}, 3 \mathrm{H}) ;{ }^{13} \mathrm{C}$ NMR $\left(125 \mathrm{MHz}, \mathrm{CDCl}_{3}\right): \delta(\mathrm{ppm})$ $148.65,148.25,147.57,145.73,145.24,145.21,145.19,144.82,144.73,144.68,144.64,144.62$, $144.50,144.24,143.83143 .13,143.05,143.01,142.93,142.27,142.14,140.95,140.72,138.53$, $138.04,134.74,131.97,122.25,78.11,72.20,72.16$ 71.27, 59.18, 45.76, 23.71, 15.63; MALDI TOFMS: $m / z 932\left(\mathrm{M}^{-}\right)$, calculated for $\mathrm{C}_{71} \mathrm{H}_{16} \mathrm{O}_{2} \mathrm{~S}, \mathrm{~m} / z$ 932.09.

\subsubsection{Synthesis of 1-(5-ethyl-2-thienyl)-1-[2-(2methoxyethoxy)ethoxy]methyl-[6,6]- methanofullerene-[60] (2)}

\subsubsection{5-Ethyl-2-thienyl [2-(2-methoxyethoxy)ethoxy]methyl ketone (10)}

To a solution of 2-[2-(methoxyethoxy)ethoxy]acetic acid $8(5.17 \mathrm{~g}, 29.0 \mathrm{mmol})$ in anhydrous dichloromethane $(20 \mathrm{~mL})$ was added oxalyl chloride (4.06 g, $32.0 \mathrm{mmol})$ under Ar atmosphere, and the solution was stirred for $5 \mathrm{~h}$ at room temperature. Then, 2-ethylthiophene $(3.17 \mathrm{~g}, 28.2 \mathrm{mmol})$ was added at $0{ }^{\circ} \mathrm{C}$, followed by the addition of $1.0 \mathrm{M}$ tin(IV) chloride in dichloromethane $(32 \mathrm{~mL})$. The reaction mixture was stirred for another $16 \mathrm{~h}$. Then $c a .70 \mathrm{~mL}$ of $1.0 \mathrm{M}$ hydrochloric acid was added to quench the reaction. The solution was transferred to a separatory funnel, and washed with distilled water and with brine until the washing was neutral. The organic layer was dried over 
anhydrous sodium sulfate, and then evaporated. Purification with silica gel chromatography (ethyl acetate: $n$-hexane $=1: 1)$ afforded ketone 10 in $614 \mathrm{mg}(8 \%)$ yield.

10: ${ }^{1} \mathrm{H}$ NMR (500 MHz, $\left.\mathrm{CDCl}_{3}\right): \delta(\mathrm{ppm}) 7.71(\mathrm{~d}, 1 \mathrm{H}, 4.0 \mathrm{~Hz}), 6.84$ (d, $\left.1 \mathrm{H}, 3.5 \mathrm{~Hz}\right), 4.63(\mathrm{~s}, 2 \mathrm{H}), 3.79$

(t, 2H), $3.71(\mathrm{t}, 2 \mathrm{H}), 3.68(\mathrm{t}, 2 \mathrm{H}), 3.56(\mathrm{t}, 2 \mathrm{H}), 3.38(\mathrm{~s}, 3 \mathrm{H}), 2.89(\mathrm{q}, 2 \mathrm{H}), 1.33(\mathrm{t}, 3 \mathrm{H}) ;{ }^{13} \mathrm{C}$ NMR $(125$ $\mathrm{MHz} \mathrm{CDCl}_{3}$ ): $\delta$ (ppm) 189.64, 157.67, 138.48, 133.16, 125.05, 74.46, 71.88, 70.45, 70.69, 70.49, $59.01,23.96,15.57$.

\subsubsection{N'-\{1-(5-Ethyl-2-thienyl)-2-[2-(2-methoxyethoxy)ethoxy]ethylidene\}-4-} methylbenzene-sulfonohydrazide (11)

A solution of ketone 10 (500 mg, $1.84 \mathrm{mmol})$ and $p$-toluenesulfonyl hydrazide (410 mg, $2.20 \mathrm{mmol})$ in ethanol $(10 \mathrm{~mL})$ was stirred for $24 \mathrm{~h}$ at room temperature. Completion of the reaction was monitored by reverse phase HPLC (acetonitrile:water $=1: 1$ ) with the loss of the peak of the starting material. The product $\mathbf{1 1}$ was isolated with silica gel chromatography (ethyl acetate: $n$-hexane $=1: 1$ ). The yield was $656 \mathrm{mg}(81 \%)$.

11: ${ }^{1} \mathrm{H}$ NMR (500 MHz, $\left.\mathrm{CDCl}_{3}\right): \delta(\mathrm{ppm}) 9.70(\mathrm{~s}, 1 \mathrm{H}), 7.87$ (d, 2H, $\left.8.5 \mathrm{~Hz}\right), 7.28$ (d, 2H, $\left.8.0 \mathrm{~Hz}\right), 6.97$ (d, 1H, $4.0 \mathrm{~Hz}), 6.61$ (d, 1H, $3.5 \mathrm{~Hz}), 4.57$ (s, 2H), $3.68(\mathrm{t}, 2 \mathrm{H}), 3.64(\mathrm{t}, 2 \mathrm{H}), 3.58(\mathrm{t}, 2 \mathrm{H}), 3.53(\mathrm{t}, 2 \mathrm{H})$, 3.39 (s, 3H), 2.79 (q, 2H), 2.42 (s, 3H), 1.27 (t, 3H); ${ }^{13} \mathrm{C}$ NMR (125 MHz CDCl $): \delta(p p m) ~ 151.51$, 145.34, 143.67, 138.23, 135.95, 129.42, 128.09, 126.53, 123.66, 72.00, 70.75, 70.26, 69.93, 67.05, 59.00, 23.71, 21.59, 15.64; MALDI TOF-MS: $m / z 441(\mathrm{M}+\mathrm{H})^{+}$; Anal. Calcd for $\mathrm{C}_{20} \mathrm{H}_{28} \mathrm{~N}_{2} \mathrm{O}_{5} \mathrm{~S}_{2}$ : C, 54.52; H, 6.41; N, 6.36; S, 14.56. Found: C, 54.30; H, 6.34; N, 6.31; S, 14.76.

\subsubsection{1-(5-Ethyl-2-thienyl)-1-[2-(2-methoxyethoxy)ethoxy]methyl-[6,6]-methanofullerene} [60] (2)

Under Ar atmosphere, hydrazide $11(154 \mathrm{mg}, 0.39 \mathrm{mmol})$ and $1 \mathrm{M}$ potassium tert-butoxide in THF $(0.42 \mathrm{~mL})$ were dissolved in anhydrous ODCB $(2 \mathrm{~mL})$ and the solution was stirred for $15 \mathrm{~min}$. Then $\mathrm{C}_{60}(200 \mathrm{mg}, 0.28 \mathrm{mmol})$ was added and the mixture was heated at $130{ }^{\circ} \mathrm{C}$ for $4 \mathrm{~h}$ under Ar while irradiating with light. The target compound was separated with silica gel chromatography (toluene) and gel permeation HPLC, yielding $114 \mathrm{mg}$ (42\%) of the fullerene derivative 2 .

2: ${ }^{1} \mathrm{H}$ NMR (500 MHz, $\left.\mathrm{CDCl}_{3}\right): \delta(\mathrm{ppm}) 7.35$ (d, 1H, 3.5 Hz), 6.79 (d, 1H, $\left.3.5 \mathrm{~Hz}\right), 4.81(\mathrm{~s}, 2 \mathrm{H}), 3.91$ (t, 2H), $3.77(\mathrm{t}, 2 \mathrm{H}), 3.68(\mathrm{t}, 2 \mathrm{H}), 3.54(\mathrm{t}, 2 \mathrm{H}), 3.41(\mathrm{~s}, 3 \mathrm{H}), 2.94(\mathrm{q}, 2 \mathrm{H}), 1.42(\mathrm{t}, 3 \mathrm{H}) ;{ }^{13} \mathrm{C}$ NMR $(125$ $\left.\mathrm{MHz} \mathrm{CDCl}_{3}\right): \delta(\mathrm{ppm}) 148.61,148.24,147.58,145.72,145.24,145.20,145.18,144.82,144.72$, $144.67,144.64,144.49,144.24,143.83,143.13,143.04,143.01,142.93,142.91,142.26,142.14$, 140.94, 140.71, 138.52, 138.03, 134.78, 131.94, 122.20, 78.11, 72.10, 72.04, 71.38, 70.88, 70.80, 59.12, 23.70, 15.60; MALDI TOF-MS: $m / z 976\left(\mathrm{M}^{-}\right)$, calculated for $\mathrm{C}_{73} \mathrm{H}_{20} \mathrm{O}_{3} \mathrm{~S}, m / z 976.1$.

\subsection{Photovoltaic cells.}


2.2.1 Instrumentation. Photovoltaic cell parameters were determined with a solar simulator system, K-0208, Bunkoukeiki Co., Ltd., under simulated solar illumination (AM 1.5G, 100 mW/ $\mathrm{cm}^{2}$ ).

2.2.2. Device Fabrication. The photovoltaic cells were prepared on indium tin oxide (ITO) covered glass substrates. One-third of an ITO substrate of $25 \mathrm{~mm} \times 25 \mathrm{~mm}$ was exposed to $\mathrm{HCl}$ vapor and the substrate was wiped with acetone and ethanol, and then subjected to an ozone cleaner for $20 \mathrm{~min}$. A film of poly(3,4-ethylenedioxythiophene):poly(styrenesulfonate), abbreviated as PEDOT:PSS, (30 $\mathrm{nm}$ ) was spin coated at $5000 \mathrm{rpm}$ from an aqueous solution under ambient conditions. The substrate was dried at $200{ }^{\circ} \mathrm{C}$ for $10 \mathrm{~min}$. $\mathrm{CuPc}$ (sublimed twice) was then vacuum deposited at a rate of 0.2-0.4 $\mathrm{nm} / \mathrm{s}$. A solution of methanofullerene $50 \mu \mathrm{L}(22 \mathrm{mg} / \mathrm{mL})$ in chlorobenzene was spin coated at 2000 rpm for $40 \mathrm{~s}$ on top of the $\mathrm{CuPc}$ film, followed by annealing at $150{ }^{\circ} \mathrm{C}$ for 10 min under $\mathrm{N}_{2}$ atmosphere. A solution of titanium tetraisopropoxide $(10 \mu \mathrm{L})$ in ethanol $(3 \mathrm{~mL})$ was filtered through $0.45 \mathrm{~mm}$ poresize filter, and was then spin coated. The thin film of $\mathrm{TiO}_{\mathrm{x}}$ was spontaneously formed via the sol-gel process. Finally, Al electrodes $(100 \mathrm{~nm})$ were deposited by thermal evaporation under vacuum at a rate of $1.0 \mathrm{~nm} / \mathrm{s}$.

\section{Results and Discussion}

3.1 Synthesis and physicochemical properties of methanofullerene derivatives. We employed a thienyl group as one of the side chain of methanofullerene. Fullerene derivatives with a thienyl moiety have been used as an electron acceptor from a thiophene polymer donor such as poly(3hexylthiophene), P3HT, by Hammelen et al. [32], and by our group [33] and others [34,35,36,37,38]. Hammelen et al. reported that the thiophene-appended methanofullerene showed similar electron mobility to that of PCBM [32]. As the other side chain, we introduced an ethyleneoxy group to provide polar properties (Chart 1). Several fullerene derivatives with ethyleneoxy side chain(s) [38,39] have been reported as an acceptor of OPVs, for diverse purposes such as electron buffer layer [40,41] and improved adhesion to metal oxide layers such as $\mathrm{ZnO}$ in inverted bulk heterojunction polymer solar cells [42]. Polyethylene glycol (PEG) has also been used to organize the $p-n$ bulk heterojunction of OPVs: PEG-appended $\mathrm{C}_{60}$ was added to P3HT-PCBM heterojunction OPVs to improve their performance $[43,44,45,46]$.

Two fullerene derivatives 1 and 2 were prepared according to Scheme 1. The diazoalkane addition to $\mathrm{C}_{60}$, followed by photochemical isomerization to the [6,6] isomer gave fullerenes 1 and 2 in $42-43 \%$ yield [47] As a reference compound, nonyl substituted derivative 3 was also prepared [48]. Methanofullerenes were purified by gel permeation HPLC. Acylthiophenes 6 and 10, $p$ tosylhydrazones 7 and 11, and methanofullerene derivatives 1 and 2 were characterized by ${ }^{1} \mathrm{H}$ NMR,

${ }^{13} \mathrm{C}$ NMR and TOF-mass spectroscopy. 


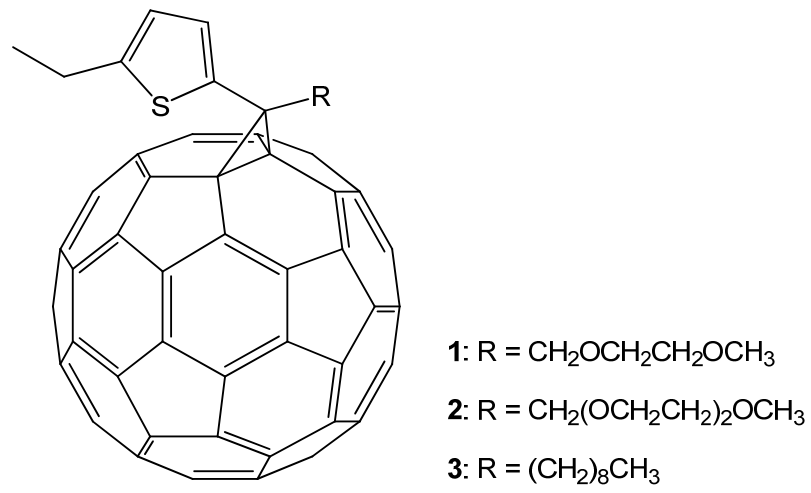

Chart 1.
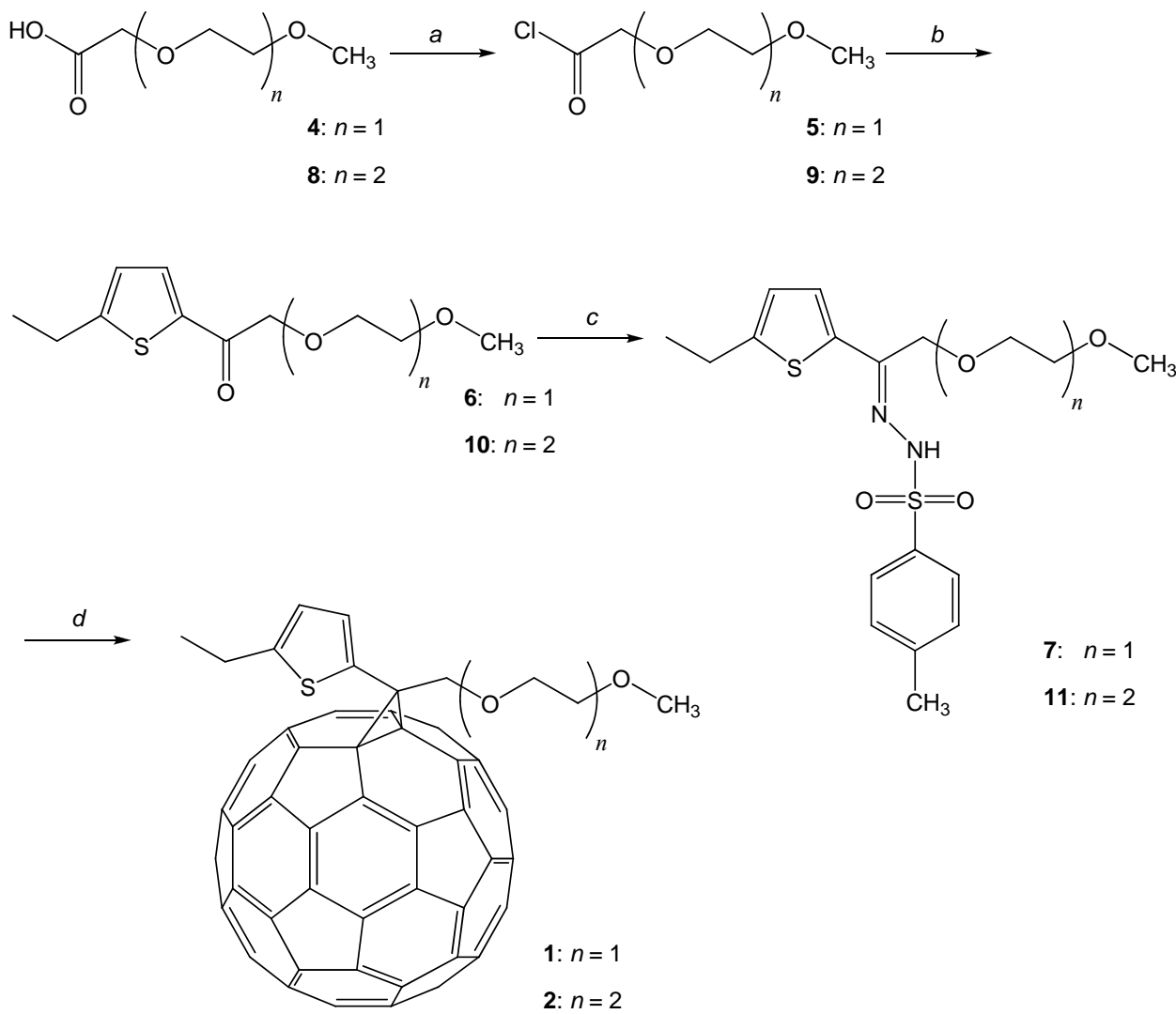

Scheme 1. Synthesis of fullerene derivatives 1 and 2. Reagents: $a$ : $(\mathrm{COCl})_{2}, \mathrm{rt}$ in $\mathrm{CH}_{2} \mathrm{Cl}_{2}, 5 \mathrm{~h}, b$ : 2ethylthiophene, $\mathrm{SnCl}_{4}$ in $\mathrm{CH}_{2} \mathrm{Cl}_{2}, \mathrm{rt}, 16 \mathrm{~h}, c$ : TsNHNH${ }_{2}$, ethanol, rt, $24 \mathrm{~h}, d: \mathrm{C}_{60},\left(\mathrm{CH}_{3}\right)_{3} \mathrm{COK}, h v, o-$ dichlorobenzene, $130{ }^{\circ} \mathrm{C}, 4 \mathrm{~h}$.

The presence of the ethyleneoxy side chain rendered the methanofullerene derivatives highly polar 
nature: the $R_{\mathrm{f}}$ values of $\mathrm{SiO}_{2}$-thin layer chromatography (TLC) eluted with toluene were 0.34 for $\mathbf{1}$, 0.03 for 2, compared with 0.54 for PCBM, demonstrating that $\mathbf{1}$ and $\mathbf{2}$ were much more polar than PCBM. Solubilities of these methanofullerenes in chlorobenzene were determined by UV-visible spectroscopy: they were 23.1 (1), 24.3 (2) and $25.0 \mathrm{~g} / \mathrm{L}$ (PCBM). Thus, the methanofullerenes with an ethyleneoxy side chain showed highly polar nature and similar solubility in chlorobenzene to that of PCBM.

The surface free energy of the thin film of methanofullerenes was determined by contact angle measurements of a probe droplet of water and hexadecane on the film of these methanofullerene derivatives. When contact angle $\theta$ is determined, the surface energy of the solid is given by Young's equation gives $\gamma_{S}=\gamma_{S L}+\gamma_{L} \cos \theta$, where $S$ and $L$ denote solid and liquid phase, respectively. Direct measurement of the surface free energy of solids is generally difficult [49]. We employed the KaelbleUy method [50] to evaluate the surface energy of thin films. According to this theory, the surface energy of the liquid is given by

$$
\gamma_{L}(1+\cos \theta)=2 \sqrt{\gamma_{S}^{d} \gamma_{L}^{d}}+2 \sqrt{\gamma_{S}^{p} \gamma_{L}^{p}}
$$

where $d$ and $p$ represent dispersion and polar component of the surface energy, respectively. The surface energies are listed in Table 1. Methanofullerenes 1 and 2 showed much higher values of $\gamma_{p}$ than those of $\mathbf{3}$ and PCBM. Methanofullerenes $\mathbf{3}$ and PCBM showed lower values of $\gamma_{\mathrm{p}}$ and $\gamma_{\text {total }}$ than those of CuPc, while methanofullerenes 1 and 2 showed values of $\gamma_{\mathrm{p}}$ and $\gamma_{\text {total }}$ similar to those of CuPc. Therefore, we expect that a more stable interface is formed in the solid state between methanofullerenes 1, 2 and $\mathrm{CuPc}$ than between 3/PCBM and CuPc.

Table 1. Surface free energy $\left(\gamma^{\text {total }}\right)$, dispersion force $\left(\gamma^{\mathrm{d}}\right)$ and polar components $\left(\gamma^{\mathrm{p}}\right)$ of fullerenes and $\mathrm{CuPc}$ determined by the Kaelble-Uy method.

\begin{tabular}{cccc}
\hline Compound & $\gamma^{\mathrm{d}}\left(\mathrm{mJ} / \mathrm{m}^{2}\right)$ & $\gamma^{\mathrm{p}}\left(\mathrm{mJ} / \mathrm{m}^{2}\right)$ & $\gamma^{\text {total }}\left(\mathrm{mJ} / \mathrm{m}^{2}\right)$ \\
\hline $\mathbf{1}$ & 27.4 & 4.4 & 31.8 \\
$\mathbf{2}$ & 27.4 & 4.1 & 31.5 \\
$\mathbf{3}$ & 27.5 & 0.4 & 27.9 \\
PCBM & 27.4 & 1.9 & 29.3 \\
CuPc & 27.4 & 5.1 & 32.5 \\
\hline
\end{tabular}

3.2 HOMO and LUMO energy levels of methanofullerenes. We examined the effects of the ethyleneoxy side chain on the molecular orbital energy levels, in particular, on the LUMO energy levels, which is the key determinant of $V_{\mathrm{OC}}$. Table 2 summarizes the HOMO and LUMO energy levels calculated with ab initio molecular orbital theory at the B3LYP/6-31G(D) level [51]. The LUMO energy levels of $\mathbf{1}$ and $\mathbf{2}$ were similar to that of $\mathbf{3}$, indicating that the ethyleneoxy side chain do not 
affect the LUMO energy level. These energy levels were also similar to that of PCBM.

These results were also supported by the cyclic voltammetry studies shown in Figure 1. The first reduction potentials of $\mathbf{1}$ and $\mathbf{2}$ were similar to those of $\mathbf{3}$ and PCBM, confirming that the ethylenoxy side chain exhibited minor effects on the reduction potential of methanofullerenes (Table 3). Jo and coworkers reported that PEG appended PCBM had a slightly higher LUMO level than PCBM by $c a$. $0.1 \mathrm{eV}$ based on cyclic voltammetry measurements [45]. The photoelectron transfer from CuPc to fullerenes is energetically favorable, and have been reported in a number of studies $[4,20]$

Table 2. HOMO, LUMO energy levels of methanofullerenes 1-3, PCBM, and $\mathrm{C}_{60}$ calculated by Gaussian at the B3LYP/6-31G (D) level.

\begin{tabular}{ccc}
\hline Compound & HOMO $(\mathrm{eV})$ & LUMO $(\mathrm{eV})$ \\
\hline $\mathbf{1}$ & -5.56 & -3.01 \\
$\mathbf{2}$ & -5.55 & -3.01 \\
$\mathbf{3}$ & -5.65 & -3.09 \\
$\mathrm{PCBM}$ & -5.60 & -3.04 \\
$\mathrm{C}_{60}$ & -5.99 & -3.22 \\
\hline
\end{tabular}

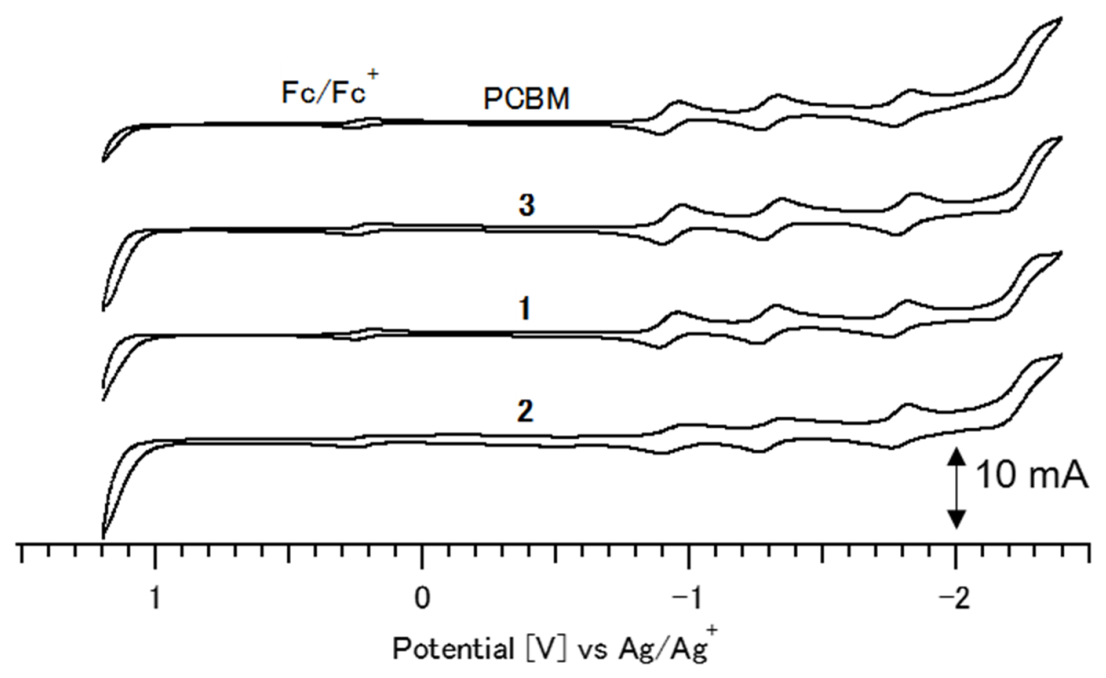

Figure 1. Cyclic voltammograms of methanofullerenes 1-3 and PCBM. 
Table 3. First reduction potentials of 1, 2, 3 and PCBM determined by cyclic voltammetry.

\begin{tabular}{cc}
\hline Compound & $E_{\text {red }}(\mathrm{V})^{1)}$ \\
\hline $\mathbf{1}$ & -1.15 \\
$\mathbf{2}$ & -1.15 \\
$\mathbf{3}$ & -1.16 \\
PCBM & -1.15
\end{tabular}

1) Volts versus ferrocene/ferrocenium couple $\left(\mathrm{Fc} / \mathrm{Fc}^{+}\right)$, used as an internal standard, in ODCB containing $0.1 \mathrm{M} \mathrm{Bu}_{4} \mathrm{NClO}_{4}$, Scan rate : $20 \mathrm{mVs}^{-1}$.

\subsection{Organic photovoltaic cell with the structure of} ITO/PEDOT:PSS/CuPc/fullerenes/TiO ${ }_{\mathbf{x}} / \mathrm{Al}$. Employing these methanofullerene derivatives, we fabricated bilayer heterojunction photovoltaic cells, in which a donor and an acceptor materials are stacked with a planar interface. $\mathrm{CuPc}$ was used as a donor. Energetics of photoelectron transfer from $\mathrm{CuPc}$ to fullerene in the solid state has been studied in detail $[52,53]$. Although a bilayer heterojunction cell generally shows lower energy conversion efficiency than those of a bulk heterojunction cell, a simpler structure of the former would lead to clearer insight into the effects of side chains on the cell performance. We used PEDOT:PSS as the electron transport layer [54] and $\mathrm{TiO}_{\mathrm{x}}$ as the hole-blocking layer [55]. The thickness of the films of both of $\mathrm{CuPc}$ and methanofullerenes were $20 \mathrm{~nm}$. CuPc was vacuum deposited and methanofullerenes were spin-coated using chlorobenzene as a solvent.

The $J-V$ curves of the photovoltaic cells under AM $1.5 \mathrm{G}$ illumination at $100 \mathrm{~mW} / \mathrm{cm}^{2}$ are shown in Figure 2. The device parameters of the OPVs are listed in Table 4. It is interesting to note that the values of short-circuit current densities, $J_{\mathrm{SC}}$, of the OPVs fabricated using $\mathbf{1}$ or $\mathbf{2}$ were larger than those fabricated using 3 or PCBM. The values of $V_{\mathrm{OC}}$ were similar, as expected from the similar LUMO energy levels of these methanofullerenes. The series resistance was determined from the slope of the $J-V$ curves around $V_{\mathrm{OC}}$, and are listed in Table 5. Importance of the series resistance for the energy conversion efficiency of OPVs has been discussed [56,57,58,59]. In accordance with the larger shortcircuit current density of the OPVs composed of $\mathbf{1}$ and $\mathbf{2}$, the series resistance was also lower for these OPVs. These results suggest that similar surface free energies of the methanofullerenes and $\mathrm{CuPc}$ lead to a stable $p-n$ interface, and thus, resulting in the larger current density. The surface free energy matching decreased in the order $\mathbf{1}>\mathbf{2}>\mathrm{PCBM}>\mathbf{3}$, and the values of $J_{\mathrm{OC}}$ also decreased in this order. Therefore stronger bonding between the donor phase and the acceptor phase can result in more efficient charge separation. Lee and coworkers reported that the surface energy matching at the polymer/fullerene interfaces in bulk heterojunction OPVs improved the miscibility of the organic active layers and enhanced the energy conversion efficiency [25]. We showed here that a similar strategy can be applied to the bilayer heterojunction OPVs. 


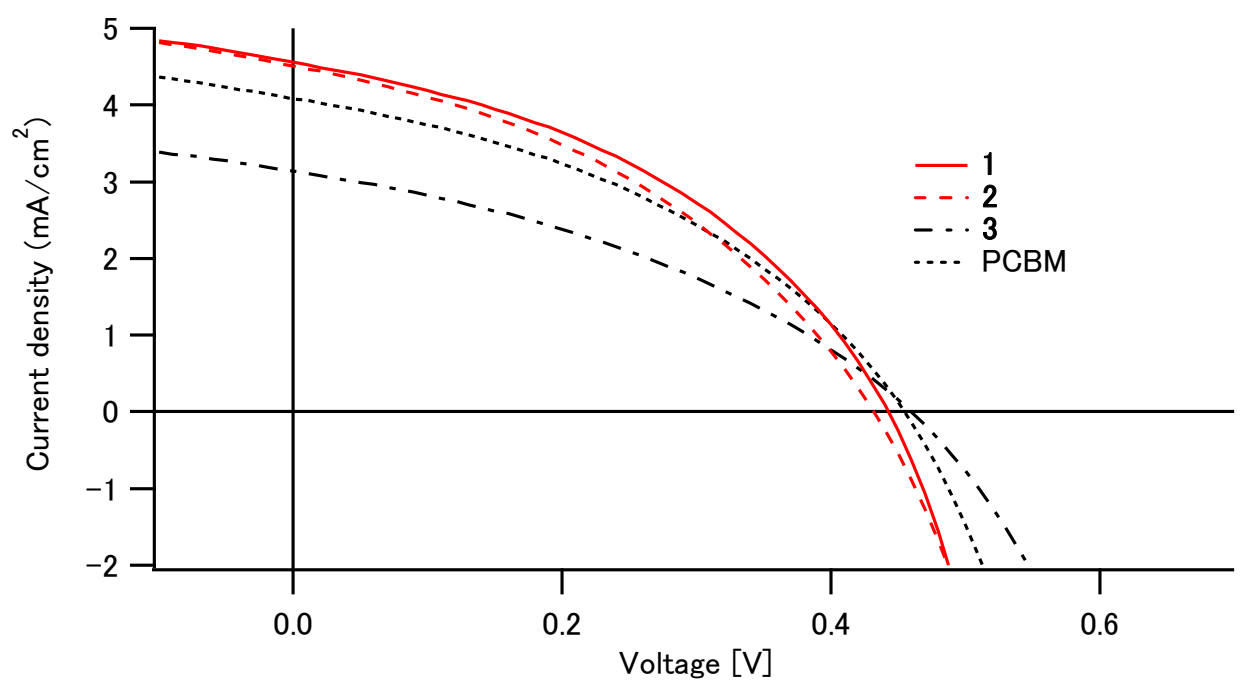

Figure 2. Current density versus voltage $(J-V)$ characteristics of organic photovoltaic cells with structure ITO/PEDOT:PSS/CuPc /methanofullerenes/TiO $/ \mathrm{Al}$ under AM $1.5 \mathrm{G}\left(100 \mathrm{~mW} / \mathrm{cm}^{2}\right)$.

Table 4. Photovoltaic parameters of methanofullerene-CuPc based photovoltaic cells fabricated with $\mathbf{1}, \mathbf{2}, \mathbf{3}$ or PCBM as an acceptor layer.

\begin{tabular}{ccccc}
\hline & $J_{\mathrm{SC}}\left(\mathrm{mA} / \mathrm{cm}^{2}\right)$ & $V_{\mathrm{OC}}(\mathrm{V})$ & $\mathrm{FF}$ & $\eta(\%)$ \\
\hline $\mathbf{1}$ & 4.56 & 0.44 & 0.41 & 0.82 \\
$\mathbf{2}$ & 4.51 & 0.43 & 0.39 & 0.76 \\
$\mathbf{3}$ & 3.14 & 0.46 & 0.37 & 0.53 \\
$\mathrm{PCBM}$ & 4.08 & 0.45 & 0.40 & 0.74 \\
\hline
\end{tabular}

Table 5. Series resistance $\left(R_{\mathrm{S}}\right)$ of CuPc-fullerene based organic photovoltaic cells employing methanofullerene derivatives 1, 2, 3 or PCBM as an acceptor.

\begin{tabular}{cc}
\hline & $R_{\mathrm{S}}\left(\Omega \mathrm{cm}^{2}\right)$ \\
\hline $\mathbf{1}$ & 29.6 \\
$\mathbf{3}$ & 35.1 \\
$\mathrm{PCBM}$ & 63.2 \\
\hline
\end{tabular}

\section{Conclusions}

Methanofullerene derivatives bearing an ethyleneoxy group were prepared. These methanofullerenes were more polar than PCBM, and their solubility in chlorobenzene was similar to that of PCBM. 
Although the surface free energies of nonylmethanofullerene 3 and PCBM were lower than that of $\mathrm{CuPc}$, the surface free energies of ethyleneoxy-appended methanofullerenes $\mathbf{1}$ and $\mathbf{2}$ were similar to that of $\mathrm{CuPc}$, indicating that the ethyleneoxy-appended methanofullerenes and $\mathrm{CuPc}$ form a stable interface. OPVs fabricated from ethyleneoxy-appended methanofullerenes showed higher shortcircuit current, and thus higher power conversion efficiency than that fabricated from PCBM. Therefore surface free energy matching between the acceptor layer and the donor layer can lead to a stable $p$ - $n$ interface, and to improve photovoltaic cell performance.

\section{Acknowledgments}

This research was supported by Core Research for Evolutional Science and Technology (CREST) of the Japan Science and Technology Agency (JST).

\section{References}

1 H. Hoppe, N. S. Sariciftci, J. Mater. Res. 2004, 19, 1924.

2 C. J. Brabec, Solar Energy Materials \& Solar Cells 2004, 83, 273.

3 G. Li, V. Shrotriya, J. Huang, Y. Yao, T. Moriarty, K. Emery, Y. Yang, Nat. Mater. 2005, 4, 864.

4 S. Guenes, H. Neugebauer, N. S. Sariciftci, Chem. Rev. 2007, 107, 1324.

5 B. Kippelen, J.-L. Bredas, Energy Environ. Sci. 2009, 2, 251.

6 T. M. Clarke, J. R. Durrant, Chem. Rev. 2010, 110, 6736.

7 M. Graetzel, R. A. J. Janssen, D. B. Mitzi, E. H. Sargent, Nature 2012, 488, 304.

8 K. A. Mazzio, C. K. Luscombe, Chem. Soc. Rev. 2015, 44, 78.

9 C. W. Tang, US Pat., 4164431 A, 1979.

10 C. W. Tang, Appl. Phys. Lett. 1986, 48, 183.

11 K. M. Coakley, M. D. McGehee, Chem. Mater. 2004, 16, 4533.G. Dennler, M. C. Scharber, C. J. Brabec, Adv. Mater. 2009, 21, 1323.

12 I. Etxebarria, J. Ajuria, R. Pacios, Organic Electronics 2015, 19, 34.

13 N. Allard, M. Leclerc, in Functional Materials, Leclerc, Mario Gauvin, Robert ed., 2014, pp. 121.

14 Y. Matsuo, Y. Sato, T. Niinomi, I. Soga, H. Tanaka, E. Nakamura, J. Am. Chem. Soc. 2009, 131, 16048 .

15 Y. He, Y. Li, Phys. Chem. Chem. Phys. 2011, 13, 1970;

16 C.-Z. By Li, H.-L. Yip, A. K.-Y. Jen, J. Mater. Chem. 2012, 22, 4161;

17 D. Mi, J.-H. Kim, H. U. Kim, F. Xu, D.-H. Hwang, J. Nanosci. Nanotechnol. 2014, 14, 1064.

18 C. L. Chochos, N. Tagmatarchis, V. G. Gregoriou, RSC Advances 2013, 3, 7160.

19 J. C. Hummelen, B. W. Knight, F. LePeq, F. Wudl, J. Org. Chem. 1995, 60, 532.

20 C.-W. Chu, V. Shrotriya, G. Li, Y. Yang, Appl. Phys. Lett. 2006, 88, 153504. 
21 C. J. Brabec, A. Cravino, D. Meissner, N. S. Sariciftci, T. Fromherz, M. T. Rispens, L. Sanchez, J. C. Hummelen, Adv. Funct. Mater. 2001, 11, 374.

22 B. P. Rand, D. P. Burk, S. R. Forrest, Phys. Rev. B 2007, 75, 115327.

23 F. Matsumoto, T. Iwai, K. Moriwaki, Y. Takao, T. Ito, T. Mizuno, T. Ohno, J. Org. Chem. 2012, $77,9038$.

24 Y. Takao, T. Masuoka, K. Yamamoto, T. Mizutani, F. Matsumoto, K. Moriwaki, K. Hida, T. Iwai, T. Ito, T. Mizuno, T. Ohno, Tetrahedron Lett. 2014, 55, 4564.

25 B. H. Lee, J. Shim, G. Kim, H. Kim, S. Song, H. Suh, K. Lee, Appl. Phys. Lett. 2012, 101, 083304.

26 J. S. Moon, C. J. Takacs, S. Cho, R. C. Coffin, H. Kim, G. C. Bazan, A. J. Heeger, Nano Lett. 2010, 10, 4005 .

27 C. V. Hoven, X.-D. Dang, R. C. Coffin, J. Peet, T.-Q. Nguyen, G. C. Bazan, Adv. Mater. 2010, 22, E63.

28 B. A. Gregg, M. C. Hanna, J. Appl. Phys. 2003, 93, 3605.

29 P. Peumans, A. Yakimov, S. R. Forrest, J. Appl. Phys., 93, 3693.

30 Y.-Y. Lai, Y.-J. Cheng, C.-S. Hsu, Energy \& Environmental Science 2014, 7, 1866.

31 P. Hudhomme, EPJ Photovoltaics 2013, 4, 40401.

32 L. M. Popescu, P. van't Hof, A. B. Sieval, H. T. Jonkman, J. C. Hammelen, Appl. Phys. Lett. 2006, 89, 213507.

33 K. Moriwaki, F. Matsumoto, Y. Takao, D. Shimizu, T. Ohno, Tetrahedron 2010, 66, 7316.

34 P. A. Troshin, H. Hoppe, J. Renz, M. Egginger, J. Y. Mayorova, A. E. Goryachev, A. S.

Peregudov, R. N. Lyubovskaya, G. Gobsch, N. S. Sariciftci, V. F. Razumov, Adv. Funct. Mater. 2009, 19, 779 .

35 H. Zhao, X. Guo, H. Tian, C. Li, Z. Xie, Y. Geng, F. Wang, J. Mater. Chem. 2010, 20, 3092.

36 J. H. Seo, S. Y. Nam, K.-S. Lee, T.-D. Kim, S. Cho, Organic Electronics 2012, 13, 570.

37 C. Saravanan, C.-L. Liu, Y.-M. Chang, J.-D. Lu, Y.-J. Hsieh, S.-P. Rwei, L. Wang, ACS Appl. Mater. Interfaces 2012, 4, 6133.6141.

38 K. Yoshimura, K. Matsumoto, Y. Uetani, S. Sakumichi, S. Hayase, M. Kawatsura, T. Itoh, Tetrahedron 2012, 68, 3605.

39 T. Shirosaki, R. Harisaki, M. Horikawa, H. Sakurai, S. Nagaoka, H. Ihara, Synth. Commun. 2014, 44, 275.

40 S.-H. Liao, H.-J. Jhuo, Y.-S. Cheng, S.-A. Chen, Adv. Mater. 2013, 25, 4766.

41 Y.-Y. Lai, P.-I. Shih, Y.-P. Li, C.-E. Tsai, J.-S. Wu, Y.-J. Cheng, C.-S. Hsu, ACS Appl. Mater. Interfaces, 2013, 5, 5122 .

42 Z.-G. Zhang, H. Li, Z. Qi, Z. Jin, G. Liu, J. Hou, Y. Li, J. Wang, Appl. Phys. Lett. 2013, 102, 143902. 
43 A. Cravino, G. Zerza, M. Maggini, S. Bucella, M. Svensson, M. R. Andersson, H. Neugebauer, N. S. Sariciftci, Chem. Commun. 2000, 2487.

44 Q. Tai, J. Li, Z. Liu, Z. Sun, X. Zhao, F. Yan, J. Mater. Chem. 2011, 21, 6848.

45 J. W. Jung, J. W. Jo, W. H. Jo, Adv. Mater. 2011, 23, 1782.

46 X.-D. Huang, S. H. Goh, S. Y. Lee, Macromol. Chem. Phys. 2000, 201, 2660.

47 R. Gonzalez, J. C. Hummelen, F. Wudl, J. Org. Chem. 1995, 60, 2618.

48 T. Ohno, Y. Takao, K. Moriwaki, F. Matsumoto, S. Uchida, S. Ikeda, PCT Int. Appl. WO-A12011010526 (2011).

49 D. E. Packham, Int. J. Adhesion Adhesives 2003, 23, 437-448.

50 D. H. Kaelble, K. C. Uy, J. Adhesion 1970, 2, 50.

51 M. J. Frisch et al., Gaussian 09, Revision A.02; Gaussian, Inc.: Wallingford, CT, 2009.

52 T. W. Ng, M. F. Lo, Z. T. Liu, F. L. Wong, S. L. Lai, M. K. Fung, C. S. Lee, S. T. Lee, J. Appl. Phys. 2009, 106, 114501.

53 T. W. Ng, M. F. Lo, Y. C. Zhou, Z. T. Liu, C. S. Lee, O. Kwon, S. T. Lee, Appl. Phys. Lett. 2009, 94, 193304.

54 F. Louwet, L. Groenendaal, J. Dhaen, J. Manca, J. Van Luppen, E. Verdonck, L. Leenders, Synthetic Metals 2003, 135-136, 115.

55 H. Derouiche, H. B. Miled, A. B. Mohamed, Phys. Status Solidi A , 2010, 207, 479.

56 J. Xue, S. Uchida, B. P. Rand, S. R. Forrest, Appl. Phys. Lett. 2004, 84, 3013.

57 R. A. Street, K. W. Song, S. Cowan, Organic Electronics 2011, 12, 244.

58 B. Qi, J. Wang, Physical Chemistry Chemical Physics 2013, 15, 8972.

59 J. D. Servaites, S. Yeganeh, T. J. Marks, M. A. Ratner, Adv. Funct. Mater. 2010, $20,97$. 